\title{
INSIGHTS INTO HYDROTHERMAL ACTIVITY IN THE ITI OPHIOLITE (CENTRAL GREECE)
}

\author{
Karipi, S. ${ }^{1}$, Tsikouras, B. ${ }^{1}$, Rigopoulos, I. ${ }^{1}$, Hatzipanagiotou, K. ${ }^{1}$, \\ and Pomonis, $\mathbf{P}^{2}$ \\ ${ }^{1}$ University of Patras, Department of Geology, Section of Earth Materials, 26500 Patras, Greece, \\ skaripi@upatras.gr,v.tsikouras@upatras.gr,rigopoul@upatras.gr,k.hatzipanagiotou@upatras.gr \\ ${ }^{2}$ University of Athens, Department of Geology and Geoenvironment, 15784 Athens, Greece, \\ ppomonis@geol.uoa.gr
}

\begin{abstract}
Scarce intensely epidotised doleritic dykes, up to $1.5 \mathrm{~m}$ thick, penetrate in sharp contact serpentinised peridotites of the remnant ophiolite nappe of the Iti ophiolite. They are generally whitish rocks characterised by distinct and irregularly distributed, olive-green areas within the rock mass. Petrographic evidence reveals that their assemblage is dominated by quartz and epidote. Albite, chlorite and titanite occur as accessory phases. Minor opaque minerals are represented by magnetite, pyrite and chalcopyrite, as well as relic Cr-spinel,. The mineral assemblage of the studied rocks comprises replacement products of the original phases under greenschist facies conditions. Moreover, the almost exclusive bi-mineralic (quartz + epidote) assemblage of the altered doleritic rocks, as well as obliteration of the original doleritic textures imply extensive recrystallisation, controlled by hydrothermal circulation. The compositions of the phases in these dykes mark the most alteration-resistant chemical components that have the potential to remain in their original associations, during such extensive recrystallisation.
\end{abstract}

Key words: epidotised dykes, dolerite, hydrothermal activity, Iti ophiolite, Central Greece.

\section{Introduction}

Ophiolites provide significant information on the geological, petrological and hydrothermal processes taken place beneath ocean ridges. A major difference between hydrothermal alteration in ophiolites and modern oceanic crust is that the former invariably exhibit evidence of extensive epidotisation relatively to the latter. Various aspects of epidosite-type alteration have been described worldwide from the Troodos (Bettison-Varga et al., 1992; Gillis, 2002; Cann and Gillis, 2004; Jowitt et al. 2007), the Semail (Stakes and Taylor, 1992), the Josephine (Alexander et al., 1993), the Tonga (Banerjee and Gillis, 2001) and the Mirdita (Muehlenbachs et al., 2004) ophiolite complexes. Several studies have also been devoted on the hydrothermal alteration in the Pindos and Othris ophiolites of Greece (Valsami, 1990; Valsami and Cann, 1992; Valsami-Jones and Cann, 1994; Valsami-Jones and Ragnarsdóttir, 1997).

The aim of this study is to describe the evolution of hydrothermally altered dolerite dykes in the Iti ophiolite. 


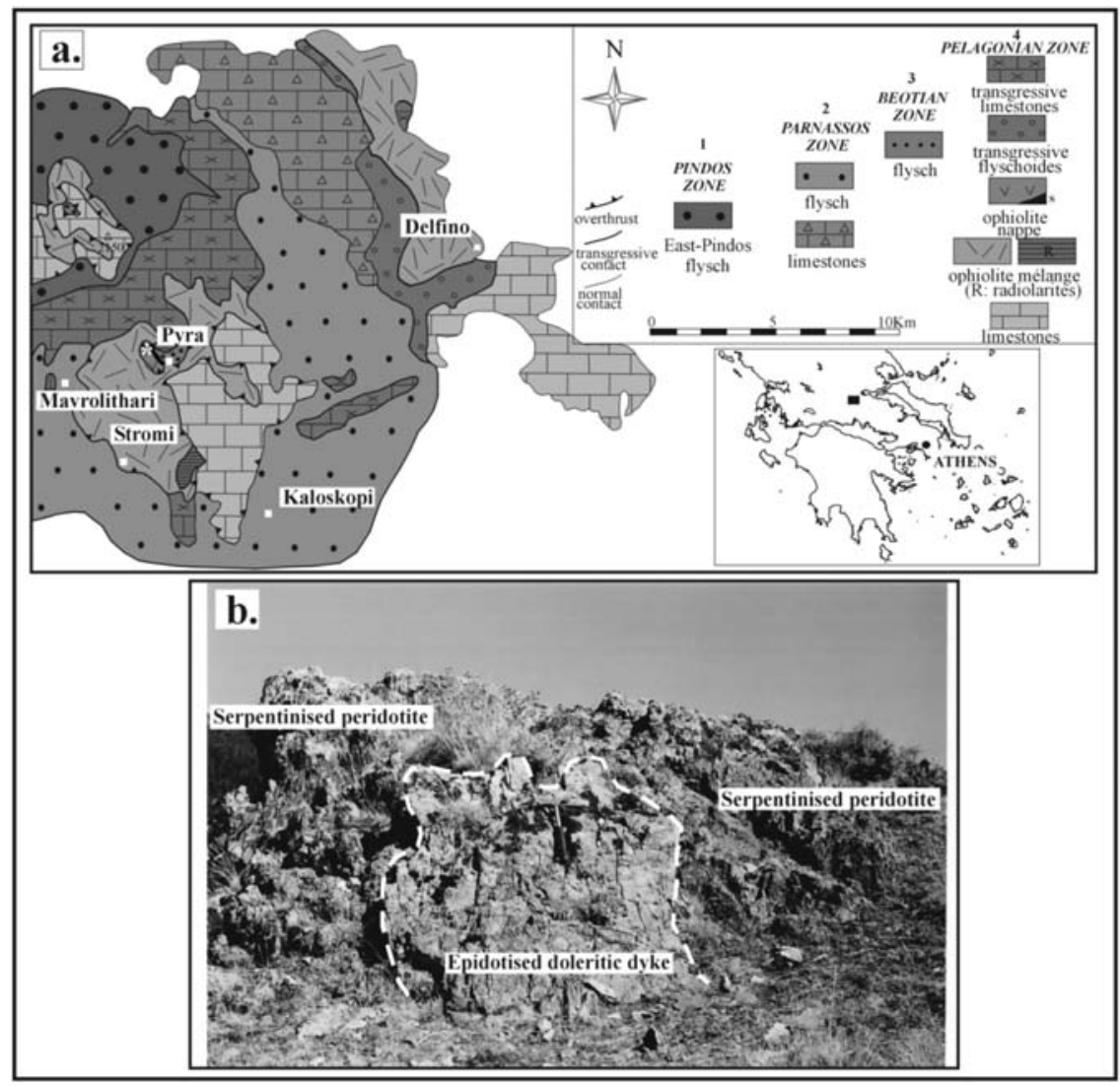

Fig. 1: (a): Simplified geological map of the Iti Mountain; asterisk (*) marks the location of the epidotised doleritic dykes, (b) outcrop of the epidotised doleritic dyke within serpentinised peridotite of the remnant ophiolite nappe.

\section{Geological setting}

The Iti Mountain lies to the south of Othrys Mountain and the Sperchios River, in continental Central Greece. It belongs to the "Pelagonia terrane" (Stampfli, 1996; Stampfli et al., 1998) a carbonate platform, equivalent to the "Internal carbonate platform" of Papanikolaou (1989). The geological structure of the Iti Mountain includes four westward verging tectono-stratigraphic zones, representing different paleotectonic domains. They comprise, from west to east: the Pindos, Parnassos, Beotian and Pelagonian zones (Wigniolle, 1977). The Iti Mountain (Fig. 1) is composed of a stack of nappe units. From bottom to top, they include: (1) the flysch of the East-Pindos syncline, (2) Mesozoic platform carbonates along with flysch of the Parnassos zone, (3) the Beotian flysch, (4) the Jurassic platform carbonates of the Pelagonian zone, and the overthrust ophiolite unit (Celet, 1976; Celet et al., 1977; Richter et al., 1997). The latter includes a lower ophiolite mélange, which is locally, tectonically overlain by a sub-ophiolitic metamorphic sole (s). Both formations are overthrust by a remnant ophiolite nappe of upper mantle tectonites (harzburgite and lherzolite; Karipi, 2004; Karipi et al., 2006; Karipi et al., 2008). The ophiolite unit is transgressively overlain by Upper Cretaceous formations (Celet, 1962; Wigniolle, 1977). 

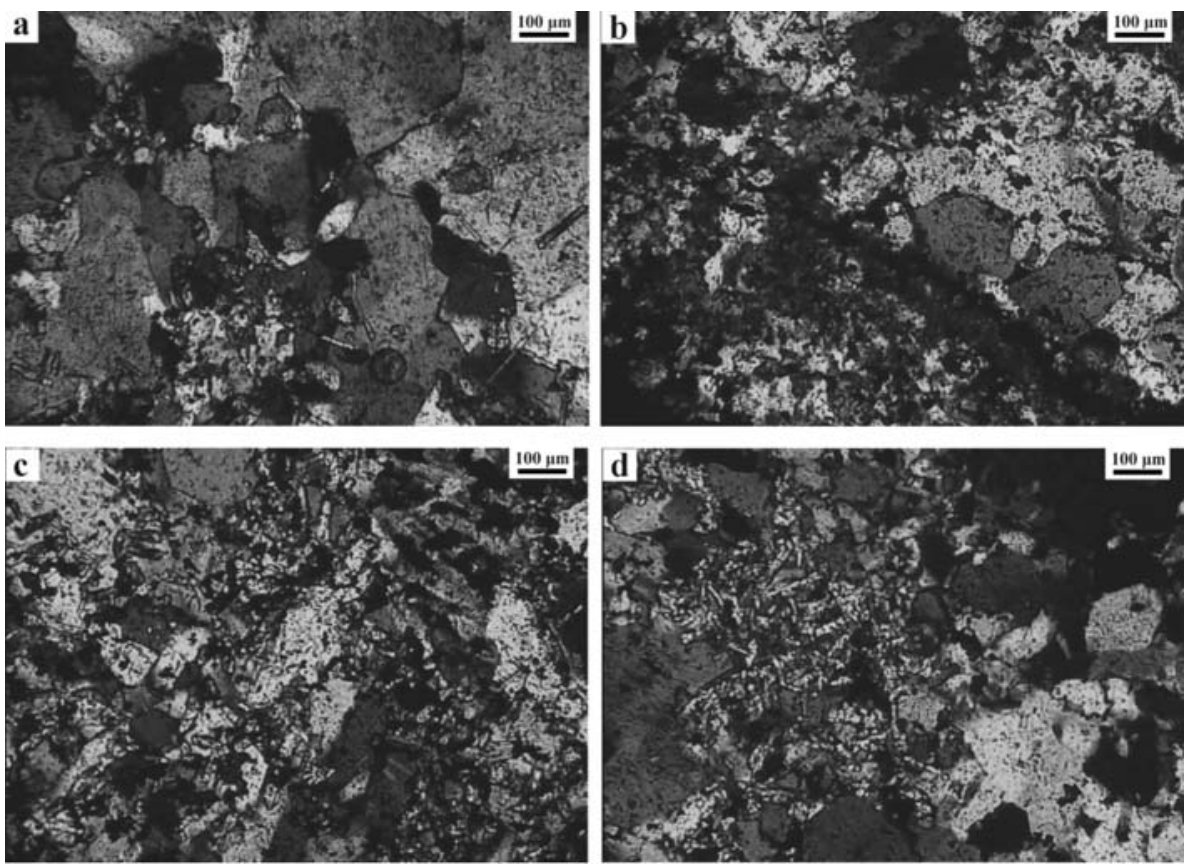

Fig. 2: (a-d): Photomicrographs (XPL) of epidotised dolelitic dyke from Iti showing the main mineral constitutes, quartz (qz) and epidote (ep), developing granoblastic (qz, ep) and tiny, embryonic crystals (ep).

Rare epidotised dykes, up to $1.5 \mathrm{~m}$ thick, trending NNE-SSW crosscut variably serpentinised peridotite, in an area northwest of the Pyra village (Fig. 1a; Mavri Tsouma). The epidotised dykes are in sharp contact with the peridotite host that belongs to the remnant ophiolite nappe (Fig. 1b). They are generally whitish rocks, characterized by distinct and irregularly distributed olive-green patches due to the presence of epidote.

\section{Petrography}

The epidotised dolerite is mainly composed of quartz, epidote and accessory albite, chlorite and titanite. Minor opaque minerals are represented by magnetite, pyrite, chalcopyrite and relic $\mathrm{Cr}$-spinel. Original textures are obliterated by granoblastic, poikiloblastic and locally cataclastic textures. Typically poikiloblastic epidote forms in a granoblastic matrix of quartz and epidote crystals of variable size (Figs. 2a, b); epidote also shows aggregates of tiny, embryonic crystals filling the quartz interstices (Figs. 2c, d). The poikiloblastic epidote crystals are either homogeneous or inhomogeneous with irregularly distributed rich and poor in pistacite component areas (Figs 3a, b). Local relics of dolerite with subophitic plagioclase and altered clinopyroxene have been observed.

\section{Analytical Methods}

Electron microanalyses were carried out at the Laboratory of Electron Microscopy and Microanalysis, University of Patras. All elements were analyzed by an electron-dispersive X-Rays (EDX) using EDS and WDS detectors attached to a JEOL JSM-6300 SEM. Operating conditions were accelerating voltage $15 \mathrm{kV}$ and beam current $3.3 \mathrm{nA}$ with $4 \mu \mathrm{m}$ diameter beam. EDS and WDS spec- 

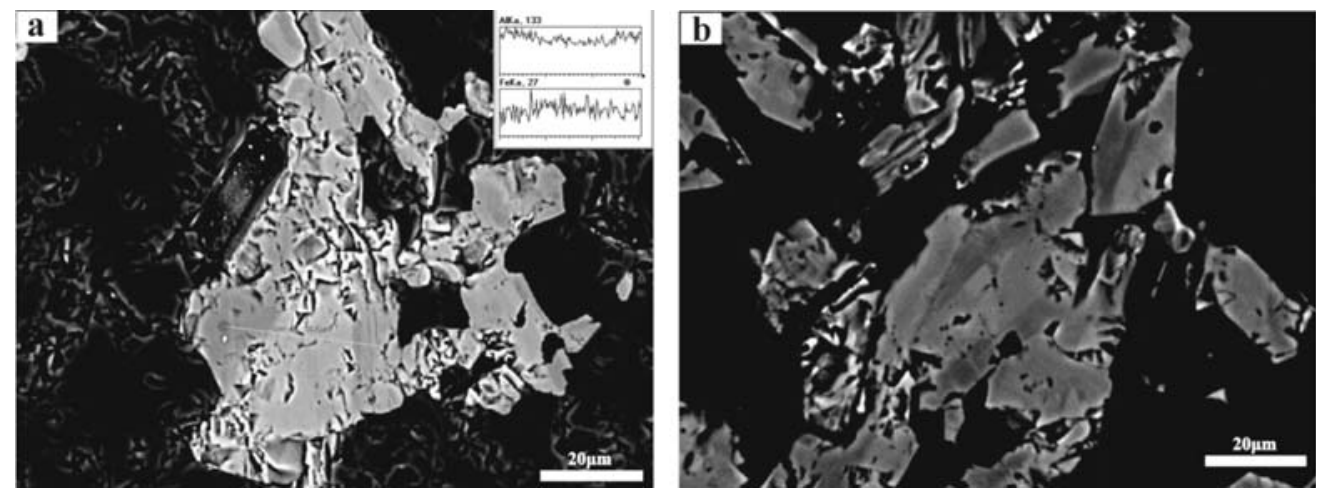

Fig. 3: Back-scatter-electron images (SEM) of inhomogeneous epidote crystals in epidotised doleritic dykes. In (a), line-scan analysis across the different compositions mainly shows variability in $\mathrm{Al}$ and $\mathrm{Fe}$ contents.

trum information with the ZAF correction software information was used. The total counting time was $60 \mathrm{sec}$ and dead-time $40 \%$. Synthetic oxides and natural minerals were utilized as standards for our analyses. Detection limits are $\sim 0.1 \%$ and an accuracy better than $5 \%$ was obtained.

\section{Mineral Chemistry}

Representative microanalyses of epidote, chlorite and plagioclase from the epidotised doleritic dykes of Iti are given in Table 1. The analysed epidotes show variable contents of $\mathrm{Fe}^{3+}$ (stoichiometric calculations assuming total $\mathrm{Fe}$ as $\mathrm{Fe}^{3+}$ ) and $\mathrm{Al}^{\mathrm{VI}}$ (see Table 1 and Fig. 3a). Pistacitic (Ps) contents range from $11.9 \%$ to $34.4 \%$ (Table 1 ).

The analysed chlorites plot in the pycnochlorite and clinochlore fields on the classification diagram of chlorites (after Hey, 1954; not shown) and they display a rather broad $\mathrm{Fe}^{\mathrm{t}} /\left(\mathrm{Fe}^{\mathrm{t}}+\mathrm{Mg}\right.$ ) variation (Table 1).

The analysed plagioclases are albites with An contents ranging up to 6.8 and negligible Or (Table 1).

\section{Hydrothermal alteration of the Iti ophiolite: Discussion and Conclusions}

Hydrothermal systems beneath ocean ridges have been summarized by Alt (1995). Hydrothermal circulation beneath ocean ridges is a fundamental process governing the heat transfer and chemical compositions of ocean crust. It was generally considered that penetration of seawater into fast-spread ocean crust is rapidly decreased beneath sheeted dike complex due to closing of fractures by precipitation of minerals (Lister, 1974; Mevel and Cannat, 1991). Chloritisation, sericitisation, silicification, and pyritisation are well-known alteration features associated with volcanogenic massive sulphide ore deposits related to ophiolites and other submarine and non-oceanic contexts (Honnorez et al., 1998). Our knowledge of the deep portions of hydrothermal upflow zones only comes from ophiolites, where epidosites are thought to indicate the root zones of upflow zones at the base of the sheeted dyke complex (Richardson et al., 1987; Schiffman et al., 1987; Harper et al., 1988; Nehlig et al., 1994). Epidosites are well documented in suprasubduction-zone ophiolites (Richardson et al., 1987; Schiffman et al., 1987; Harper et al., 1988; Nehlig et al., 1994) whereas they are rare in rock collections from modern oceanic setting. According to Banerjee et al. (2000), epidosites discovered from the Tonga forearc representing the first documented suite recovered from a modern oceanic set- 


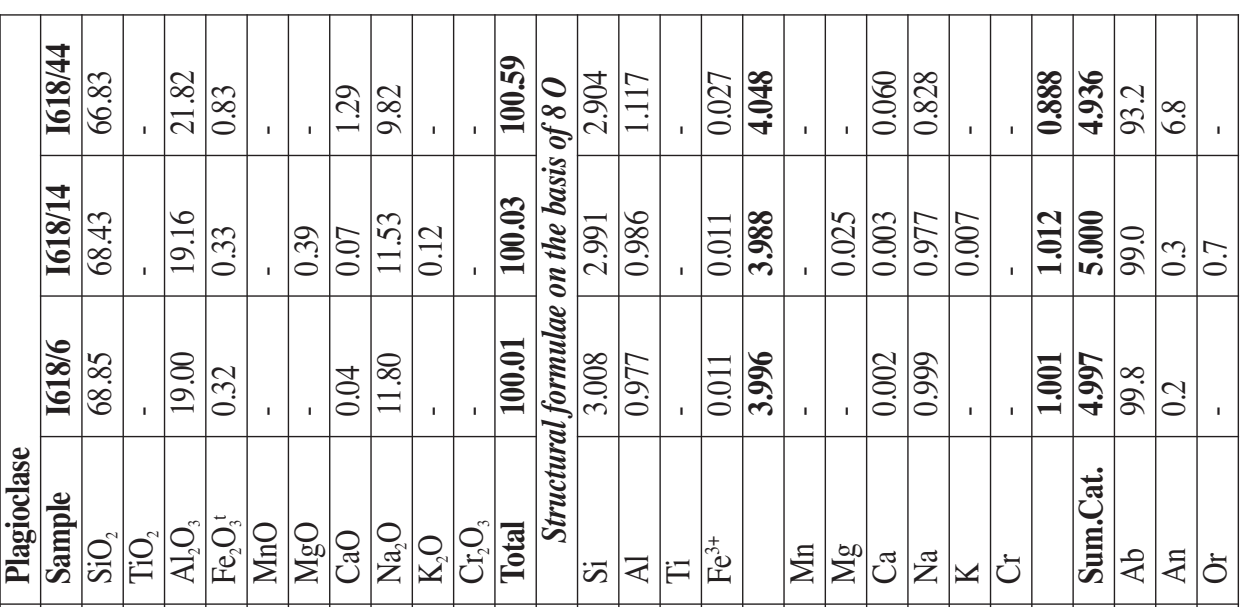

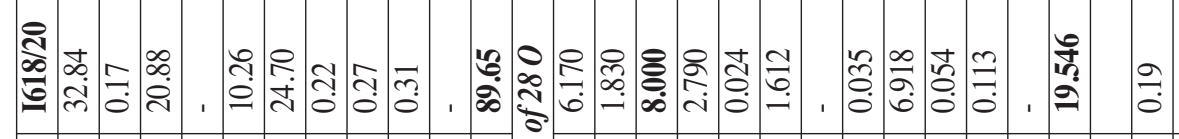

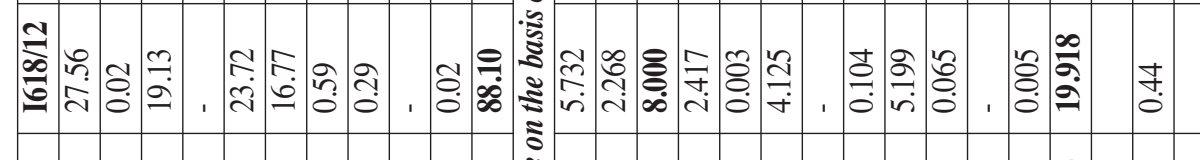

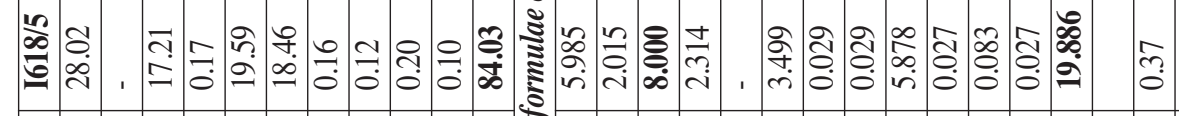

.8

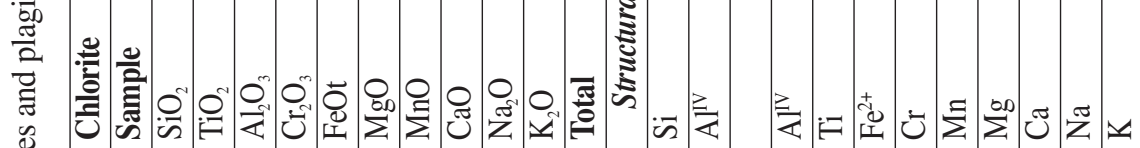

产

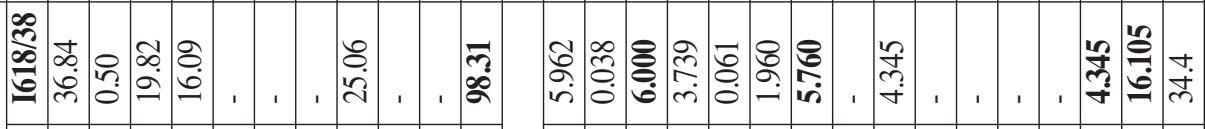

$\frac{0}{0}$

๓

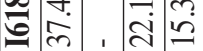

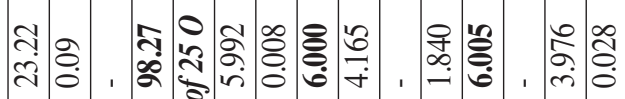

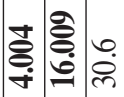

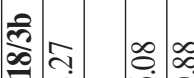

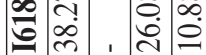

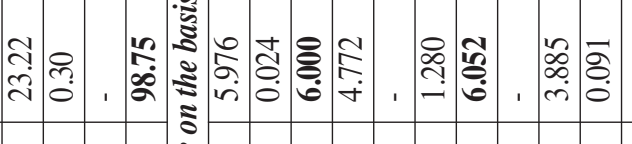

ะัญัญ

을

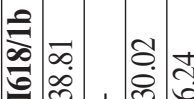

ฉุ

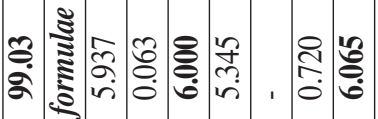

సે.

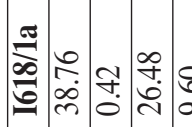

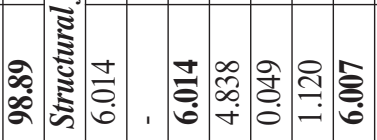

ลิ

.

ن.

$\frac{\text { ह }}{\sqrt{0}}$ 
ting that may represent a modern analogue for the tectonic setting in which suprasubduction-zone ophiolites formed.

The Iti epidosites are characterised by metasomatic replacement of primary igneous minerals by granoblastic and poikiloblastic assemblages of quartz + epidote \pm albite \pm chlorite \pm titanite \pm magnetite \pm sulfides. Mineral chemistry reveals that epidote, chlorite and plagioclase from the Iti epidosites have a range in composition similar to that of ophiolite-hosted epidosites (e.g. Schiffman and Smith, 1988; Nehlig et al. 1994) and Tonga forearc ones (Banerjee et al., 2000). The above-mentioned mineral assemblage indicates that the Iti dolerites underwent hydrothermal alteration under greenschist facies conditions. According to Banerjee et al., (2000), epidosites formed by pervasive alteration of basalt at greenschist facies conditions and at high water-rock ratios. The Iti epidosites could be characterised as true epidosites as they are mainly composed of quartz and epidote with minor albite and other phases. According to Cowan (1989) and Schiffman et al. (1990), the transformation of basalt to a true epidosite involves considerable chemical change. On the scale of an epidosite zone, the sheeted dykes are consistently depleted in $\mathrm{Na}$ and $\mathrm{K}$ and are enriched in $\mathrm{Si}$. The extent of $\mathrm{Mg}$ and $\mathrm{Ca}$ mobility is more variable, such that chlorite-rich epidosites are enriched in $\mathrm{Mg}$ and depleted in $\mathrm{Ca}$, whereas chlorite-poor rocks show the opposite trends. In terms of chemical components, the Iti epidosites are dominated by quartz and Ca-rich minerals such as epidote \pm titanite whereas they contain only minor amounts of albite and $\mathrm{Mg}(\mathrm{Fe})$-rich minerals as chlorite. This almost bi-mineralic assemblage (quartz + epidote) of the Iti epidosites could imply that the hydrothermal fluids that metasomatically altered precursor dolerite were depleted in $\mathrm{Mg}$ and alkalis while enriched in Si and Ca. According to other well-documented ophiolitic epidosites (e.g. Richardson et al., 1987; Nehlig et al., 1994), these highly focused upflow hydrothermal fluids that circulated in the Iti ophiolite caused intensive alteration at the deeper portion of the dolerite dyke intruded the upper mantle peridotites. The irregular distribution of variable Ps components in the epidote crystal is possibly related to changes of the composition of the fluid phase and different fluid pulses that likely were evolving in composition as they were interacting with the peridotite and the dolerite. Hence, it is probable that the fluid phase was recirculated through the serpentinite, slightly adjusting its composition during chemical modifications that were taking place due to fluid-rock interaction.

The Iti epidosite could be thus interpreted as has been formed via extreme geochemical and mineralogical transformations at temperatures up to $400^{\circ} \mathrm{C}$ within reaction zones and deep hydrothermal discharge zones (epidosite zones). These conditions are also consistent with the frame of epidote formation, as according to Schiffman (1995) and Bird and Spieler (2004), hydrothermal epidote from ophiolite sequences forms during intense fluid-rock interaction at temperatures between 300 and $400^{\circ} \mathrm{C}$.

\section{References}

Alexander, R.J., Harper, G.D., and Bowman, J.R., 1993. Oceanic faulting and fault-controlled subseafloor hydrothermal alteration in the sheeted dike complex of the Josephine Ophiolite, Journal of Geophysical Research, 98, 9731-9759.

Alt, J.C., 1995. Subseafloor processes in mid-ocean ridge hydrothermal systems. In S. Humphris, J. Lupton, L. Mullineaux and R. Zierenberg (eds.), Seafloor Hydrothermal System: Physical, Chemical, Biological and Geological Interpretation. Geophysical Monograph, 91, 85-114. Amerian Geophysical Union, Washington D. C.

Banerjee, N.R., and Gillis, K.M., 2001. Hydrothermal alteration in a modern suprasubduction zone: The Tonga forearc crust, Journal of Geophysical Research, 21, 737-750.

Banerjee, N.R., Gillis, K.M., and Muehlenbachs, K., 2000. Discovery of epidosites in a modern oceanic 
setting, the Tonga forearc, Geology, 28(2), 151-154.

Bettison-Varga, L., Varga, R.J., and Schiffman, P., 1992. Relation between ore-forming hydrothermal systems and extensional deformation in the Solea graben spreading center, Troodos ophiolite, Cyprus, Geology, 20, 987-990.

Bird, D.K., and Spieler, A.R. 2004. Epidote in Geothermal Systems, Reviews in Mineralogy and Geochemistry, 56(1), 235-300.

Cann, J., and Gillis, K., 2004. Hydrothermal insights from the Troodos ophiolite, Cyprus. In E.E. Davis and H. Elderfield (eds.), Hydrogeology of the Oceanic Lithosphere. 274-310, Cambridge University Press.

Celet, P., 1962. Contribution à l'étude géologique du Parnasse-Kiona et d'une partie des regions méridionales de la Grèce continentale, Annalles Géologiques des Pays Helléniques, 13, 446pp.

Celet, P., 1976. À propos du mélange de type "volcano-sédimentaire” de l'Iti (Grèce méridionale), Bulletin de la Société Géologique de France, 18, 299-307.

Celet, P., Ferrière, J., and Wigniolle, E., 1977. Le problème de l'origine des blocs exogènes du mélange à elements ophiolitiques au Sud du Sperchios et dans le massif de l'Othrys (Grèce), Bulletin de la Société Géologique de France, 19(4), 935-942.

Cowan, J.G., 1989. Geochemistry of reaction zone source rocks and black smoker fluids in the Troodos ophiolite, Ph.D. Thesis, University of Newcastle-upon-Tyne.

Gillis, K.M., 2002. Root-zones of a fossil oceanic hydrothermal system exposed in the Troodos Ophiolite, The Journal of Geology, 110, 57-74.

Harper, G.D., Bowman, J.R, and Kuhns, R.J., 1988. A field, chemical, and stable isotope study of subseafloor metamorphism of the Josephine Ophiolite, California-Oregon, Journal of Geophysical Research, 93, 4625-4656.

Hey, M.H., 1954. A new review on the chlorites, Mineralogical Magazine, 224, 277-298.

Honnorez, J.J., Alt, J.C., and Humphris, S.E., 1998. Vivisection and autopsy of active and fossil hydrothermal alterations of basalt beneath and within the TAG hydrothermal mound. In P.M. Herzig, S.E. Humphris, D.J. Miller and R.A. Zierenberg (eds.), Proceedings of the Ocean Drilling Program, Scientific Results, Vol. 158.

Jowitt, S.M., Jenkin, G.R., Coogan, L.A., Naden, J., and Chenery, S.R.N., 2007. Epidosites of the Troodos Ophiolite: A direct link between alteration of dykes and release of base metals into ore-forming hydrothermal systems? $9^{\text {th }}$ Biennial SGA Meeting, Mineral Exploration and Research: Digging Deeper, $20^{\text {th }}-23^{\text {rd }}$ August 2007.

Karipi, S., 2004. The ophiolitic outcrops of Iti and Kallidromon. Geological study - Petrogenetic evolution - Geotectonic interpretation, Ph.D. Thesis, University of Patras, 417pp.

Karipi, S., Tsikouras, B., and Hatzipanagiotou, K., 2006. The petrogenesis and tectonic setting of ultramafic rocks from Iti and Kallidromon Mountains, continental Central Greece: vestiges of the Pindos ocean, Canadian Mineralogist, 44(1), 267-287.

Karipi, S., Tsikouras, B., Pomonis, P., and Hatzipanagiotou, K., 2008. Geological evolution of the Iti and Kallidromon Mountains (central Greece), focused on the ophiolitic outcrops, Zeitschrift der Deutschen Gesellschaft für Geowissenschaften, 159(3), 549-563.

Lister, C.R.B., 1974. On the penetration of water into hot rock, Geophysical Journal of Royal Astronomical Society, 39, 465-509.

Mevel, C., and Cannat, M., 1991. Lithospheric streching and hydrothermal processes in oceanic gabbros from slowspreading ridges. In Tj. Peters et al. (ed.), Ophiolite Genesis and Evolution of the Oceanic Lithosphere, Ministry of Petroleum and Minerals, Sultanate of Oman, 293-312. 
Muehlenbachs, K., Banerjee, N.R., Dilek, Y., Furnes, H., and Shallo, M., 2004. Seafloor hydrothermal alteration of the crustal sequence of the Mirdita ophiolite, Albania. $32^{\text {nd }}$ International Geological Congress, Florence, Italy, 20-28/8/2004.

Nehlig, P., Juteau, T., Bendel, V., and Cotten, J., 1994. The rootzones of oceanic hydrothermal systems: constraints from the Samail ophiolite (Oman), Journal of Geophysical Research, 99, 4703-4713.

Papanikolaou, D., 1989. Are the medial crystalline massifs of the Eastern Mediterranean drifted Godwanian fragments?, Geological Society of Greece, Special Publication, 1, 63-90.

Richardson, C.J., Cann, J.R., Richards, H.G., and Cowan, J.G., 1987. Metal-depleted root zones of the Troodos ore-forming hydrothermal systems, Cyprus, Earth and Planetary Science Letters, 84, 243 253.

Richter, D., Mihm, A., and Müller, C., 1997. Die pelagonischen Deckenreste auf dem Flysch des Ostpindos-Synklinoriums (Pindos-Zone) westlich des Iti-Gebirges (Mittelgriechenland), Zeitschrift der Deutschen Geologischen Gesellschaft, 148(2), 237-246.

Schiffman, P., 1995. Low grade metamorphism of mafic rocks. Geological Society of America, Special Paper 296.

Schiffman, P., Bettison, L.A., and Smith, B.M., 1990. Mineralogy and geochemistry of epidosites from the Solea graben, Troodos ophiolite, Cyprus. In J. Malpas, E. Moores, A. Panayiotou, and C. Xenophontos (eds.), Ophiolites: Oceanic Crustal Analogues. Nicosia: Cyprus Geological Survey Department, pp. 673-684.

Schiffman, P., and Smith, B.M., 1988. Petrology and oxygen isotope geochemistry of a fossil seawater hydrothermal system within the Solea Graben, Northern Troodos Ophiolite, Cyprus, Journal of Geophysical Research, 93, 4612-4624.

Schiffman, P., Smith, B.M., Varga, R.J., and Moores, E.M., 1987. Geometry, conditions, and timing of offaxis hydrothermal metamorphism and ore-deposition in the Solea Graben, Nature, 325, 423-425.

Stakes, D.S., and Taylor, H.P., 1992. The Northern Semail Ophiolite: an oxygen isotope, microprobe and field study, Journal of Geophysical Research, 97(7), 43-80.

Stampfli, G.M., 1996. The Intra-Alpine terrain: A Paleotethyan remnant in the Alpine Variscides, Eclogae Geologicae Helveticae, 89(1), 13-42.

Stampfli, G.M., Mosar, J., De Bono, A., and Vavassis, I., 1998. Late Paleozoic, Early Mesozoic Plate Tectonics of the Western Tethys, Geological Society of Greece, Special Publication, Bulletin of the Geological Society of Greece, 32(1), 113-120.

Valsami, E., 1990. Geochemistry and petrology of hydrothermal discharge zones in the Pindos and Othris ophiolites, Greece, Ph.D. Thesis, University of Newcastle upon Tyne, 359pp.

Valsami, E., and Cann, J.R., 1992. Evidence for the mobility of the rare earth elements in zones of intense hydrothermal alteration in the Pindos ophiolite, Greece. In L.M. Parson, B.J. Murton, and P. Browning (eds.), Ophiolites and Their Modern Oceanic Analogues, Geological Society of London, Special Publication, 60, 219-232.

Valsami-Jones, E., and Cann, J.R., 1994. Controls on the Sr and Nd isotopic compositions of hydrothermally altered rocks from the Pindos ophiolite, Greece, Earth Planetary Science Letters, 125, 39-54.

Valsami-Jones, E., and Ragnarsdóttir, K.V., 1997. Controls on uranium and thorium behaviour in oceanfloor hydrothermal systems: examples from the Pindos ophiolite, Greece, Chemical Geology, 135, 263-274.

Wigniolle, E., 1977. Données nouvelles sur la géologie du massif de l'Iti (Grèce continentale), Annalles de la Société Géologique du Nord, 47(3), 239-251. 